\title{
Corporate Board Structure and Firm Performance: The Context of Pharmaceutical Industry in Bangladesh
}

\author{
Shobod Deba Nath ${ }^{1}$, Saiful Islam ${ }^{2}$ \& Anup Kumar Saha ${ }^{3}$ \\ ${ }^{1}$ Assistant Professor, Department of International Business, University of Dhaka, Bangladesh \\ ${ }^{2}$ Senior Lecturer, School of Business and Economics, United International University, Bangladesh \\ ${ }^{3}$ Assistant Professor, Department of Accounting \& Information Systems, Jagannath University, Bangladesh \\ Correspondence: Shobod Deba Nath, Assistant Professor, Department of International Business, University of \\ Dhaka, Bangladesh. Tel: 880-17-1226-9380. E-mail: subodh154du@yahoo.com
}

Received: April 14, 2015

doi:10.5539/ijef.v7n7p106
Accepted: April 27, 2015

Online Published: June 25, 2015

\begin{abstract}
This study examines the influence of board structure on firm's financial performance in the pharmaceutical industry of Bangladesh. Based on existing empirical studies, four major board attributes (board composition, board size, board ownership and CEO duality) have been selected to identify their influence on firm's financial performance. Tobin's Q (a market based performance measure) and Return on Asset- ROA (an accounting based performance measure) are considered as financial performance measures. Findings from the study show that there is a significant negative relation between board size and firm's financial performance. However, association between other three variables- board composition, board ownership and CEO duality with financial performance is insignificant to draw a conclusion. The study recommends smaller but representative board size for pharmaceutical companies of Bangladesh. In addition, this paper argues that as the board of directors are supposed to ensure monitoring activities to increase firm performance; the composition of outside directors as board members should be increased to make it representative.
\end{abstract}

Keywords: board structure, corporate governance, firm performance, pharmaceutical industry, Bangladesh

\section{Introduction}

The United Kingdom Cadbury Report (Cadbury, 1992, p. 15) defines corporate governance as "the system by which companies are directed and controlled", including board practices and composition and their relationship to firm performance. Corporate governance covers the concepts, theories and practices of boards and their directors and the relationship between boards and shareholders, top management, regulators and auditors and other stakeholders (Huq \& Bhuiyan, 2012). Some empirical investigations found that good corporate governance have a positive effect on firm's performance and market value (Sami, Wang, \& Zhou, 2008). Thus, the recent worldwide corporate outrages raise the necessity for evaluating performance of the board in managing firm's activities.

Board performance of its monitoring duties usually is influenced by the effectiveness of the board, which in turn is influenced by factors such as board composition and quality, size of boards, duality of CEO/Chairman positions, board diversity and ownership, information asymmetries and board culture (Brennan, 2006). The board composition refers to the ratio of non-executive directors and executive directors on the board as a means of monitoring the management (Rashid, 2009) including diversity of board members, and CEO duality. The practices of corporate board structure vary from industry to industry within a country.

Following the large number of corporate collapses around the world, considerable research on corporate governance is conducted within the developed countries context, such as the United States, the United Kingdom, Australia, Germany and Japan but such studies are not adequately conducted to date for an emerging economy, such as Bangladesh (Rashid, 2009). All these studies generated mixed result whether board structure especially dominance of outside directors, CEO duality or even board size have an impact on firm performance (Rashid, Zoysa, Lodh, \& Rudkin, 2010a).

Studies by Rashid et al. (2010a) on board composition and firm performance; Rashid (2009) on board composition, board leadership structure and firm performance in the context of Bangladesh are insufficient to 
comment about a particular industry performance as these studies focused on overall secondary market, mixing different industries. Moreover, these studies did not include all representative variables of board structure for evaluating firm's financial performance. Along with this, so far concerned, none of the studies have focused on the impact of board structure on the firm performance for pharmaceutical Industry of Bangladesh.

Pharmaceutical sector of Bangladesh is the third largest industry in terms of contribution to government's revenue (Saad, 2012). There are about 250 registered small, medium, large and multinational pharmaceutical companies (a little over 100 are operating) in the country producing around $97 \%$ of the local demand and exporting the rest. It exported worth of 3813.50 thousand taka pharmaceutical products to 83 countries including Europe and America in 2010 (Bangladesh Bureau of Statistics). Globally, Bangladesh market has demonstrated the highest growth among all countries in 2010 (IMS Health). This market scenario indicates the need for increasing firms' performance through good governance practice.

Thus the aim of this research is to examine the influence of corporate board structure on firm's performance in the pharmaceutical industry of Bangladesh. To achieve this aim, research objectives for the study are to examine the pattern of board structure in pharmaceutical companies of Bangladesh, and to examine whether different variables of board structure have any influence on firm performance in pharmaceutical companies of Bangladesh. Therefore, the study extends and contributes to the body of research using data collected on pharmaceutical companies of Bangladesh and evaluating the impact of board structure on financial performance of the companies. The outcome will be further helpful to the decision makers of pharmaceutical companies as this sector was rarely explored earlier on this regard.

The reminder of this paper is organized as follows. Section 2 reviews the literature on board structure and firm's performance especially four main board attributes- board composition, boar size, board ownership and CEO duality. The methodology of the study is proposed and described in section 3. Section 4 provides the results and discussion on statistical analysis from the collected data on different variables. Conclusions and decision implications are presented in section 5 .

\section{Literature Review}

\subsection{Board Composition and Firm's Financial Performance}

Composition of the board of directors, as a corporate governance component had recognition a growing attention for the success of a firm and consequently, practitioners and academia had tried to find a proper construction of board structure by linking this with performance (Ranasinghe, 2010). While numbers of empirical study have already done in the context of developed countries, these are inadequate for developing countries (Rashid, 2009). However, the results have been diverse (Kumar \& Singh, 2012). Postma, Ees, and Sterken, (1996) found negative relationship between the size and composition (number of outsiders) of the supervisory board and firm performance for listed Dutch firms.

Moreover, Rashid et al. (2010a) concluded that the outside (independent) directors cannot add potential value to the firm's economic performance in Bangladesh based on an observation of 274 Bangladeshi firm-years. Berkman, Cole, Lee, and Veeraraghavan (2005), Rashid and Lodh (2008) and Moscu (2013) also confirmed the negative association. However, when assessing the relationship between board composition and firm performance Rashid, Fairuz, and Husein (2010b), Awan (2012), and Liang and Li (1999) found significant positive relationship. Moreover, Callen, Klein and Tinkelman (2003), and Erhardt, Werbel and Shrader (2003), also found a positive correlation between board composition and financial performance.

However, Kumar and Singh (2012), Latif et al. (2013) and Ranasinghe (2010) found no statistically significant relationship between composition of a firm and its financial performance. Bermig and Frick (2010) and Ness, Miesing, and Kang (2010) were unable to find a consistent relationship between board size or board composition and firm performance. Moreover Chatterjee (2011), Darmadi (2010), and Shakir (2008) found inconclusive and mixed relation between board structure, specifically board composition and firm performance.

$\mathbf{H}_{1}$ : There is a negative relationship between board composition and corporate performance.

\subsection{Board Size and Corporate Financial Performance}

Board size is an important attribute of board structure. It is determined on the basis of how much it influences the communication \& coordination and control management of a firm (Saha \& Akter, 2013). While large board size is considered fruitful for firms to secure its valuable resources and to reduce uncertainties (Goodstein, Gautum, \& Boeker, 1994; Pearce \& Zahra, 1992; Pfeffer, 1983; Uadiale, 2010) some other found potential problems with it. As Yermack (1996) found that there is an impediment on firm performance when coordination, communication and decision-making are completed among large number of directors. However, larger board size 
might initially facilitate key board functions of firm which successively creates coordination and communication problems (Jensen, 1993; Lipton \& Lorsch, 1992). Thus many scholars preferred for a small board consist of eight to nine members (Jensen, 1993; Lipton \& Lorsch, 1992) which might be industry specific (Adams \& Mehran, 2003) or firm specific variables (Boone, Field, Karpoff, \& Raheja, 2007; Coles, Daniel, \& Naveen, 2008; Guest, 2008; Lehn, Sukesh, \& Zhao, 2004; Linck, Netter, \& Yang, 2008).

With some exceptions, the majority of existing empirical evidence relating to the impact of board size shows a negative result on firm's performance. Eisenberg, Sundgren, and Wells (1998) based on Yermack (1996) find negative relationship between board size and firm performance for small private firms in Finland. Moreover, Loderer and Peyer (2002), Mak and Kusnadi (2005), Haniffa and Hudaib (2006) found a significantly negative impact on Tobin's Q. Some other US empirical studies confirm the same results (Cheng, Evans, \& Nagarajan, 2007; Coles et al., 2008; Hermalin \& Weisbach, 2003; Huther, 1997). However, Dehaene, De Vuyst, and Ooghe (2001) found a positive relation between board size and company performance. Adams and Mehran (2005), Beiner, Drobetz, Schmid, and Zimmermann (2004 and 2006), Dalton, Daily, Johnson, and Ellstrand (1999) also confirm the positive effect of board size on firm performance. Connelly and Limpaphayom (2004) found no relation between board size and firm performance.

$\mathbf{H}_{2}$ : There is a negative relationship between board size and firm's financial performance.

\subsection{Board Ownership and Firm's Financial Performance}

Board ownership, the proportion of total equity owned by executive and non- executive directors, indicates the level of ownership of the directors along with their monitoring power within organization. To implement effective corporate governance, Board of directors is responsible for suggesting and implementing major strategies for the firm. However, because of agency conflict, directors often failed to represent the interest of shareholders (Saha \& Arifuzzaman, 2011). Creating a sense of ownership through board ownership is one of several means that can lessen this agency conflicts (Eisenhardt, 1989; Fauzi \& Locke, 2012; Roberts, McNulty, \& Stiles, 2005; Shleifer \& Vishny, 1997).

Several previous studies have addressed the relationship between ownership structure and firm performance and find mixed results regarding how ownership structure create impact on firms' performance. Morck, Shleifer and Vishny (1988), McConnell and Servaes (1990) found a significant relationship between managerial ownership and firm performance. However, Demsetz and Lehn (1985) found no link between ownership structure and firm performance. Moreover, from the perspective of corporate performance, Demsetz (1983) implies that increasing board ownership might reduce corporate performance. Confirming the same result, Morck et al. (1988) found that firm performance first rises as ownership increases up to $5 \%$, then falls as ownership increases up to $25 \%$ and then rises slightly at higher ownership levels.

$\mathbf{H}_{3}$ : There is a negative relationship between board ownership and firm's financial performance.

\subsection{CEO-Chairman Duality and Firm's Financial Performance}

Chief Executive Officer (CEO) duality refers to the leadership nature of board structure in which the CEO plays the dual role of chairman of the board also. There are two basic schools of scholar who debate on the issue of CEO duality and its impact on firm performance. Based on the core concept of agency theory one school of scholar supports separation of the CEO-Chairman positions would maximize firm performance (Gillan, 2006; Harris \& Helfat, 1998; Shleifer \& Vishny, 1997), as the board has a neutral authority to supervise the CEO's tasks. However, the empirical evidence for this relationship is inconclusive and mixed.

Another school of scholar supports for same position of CEO- Chairman as it reflects the stewardship theory of management. When the two positions CEO-Chairman are performed by one person, it ensures the monitoring and implementing control throughout the firm (Adams, Almeida, \& Ferreira, 2005; Davis, Schoorman, \& Donaldson, 1997; Finkelstein \& D’Aveni, 1994). Previous studies thus indicate both dual CEO and non-dual CEO firm can increase firm performance which is inconclusive to generate a single direction (Brickley, Coles, \& Jarrell, 1997; Cannella \& Lubatkin, 1993; Daily \& Dalton, 1997; Donaldson \& Davis, 1991).

$\mathbf{H}_{4}$ : There is a negative relationship between CEO duality and corporate performance.

\section{Methodology}

\subsection{Sample Selection}

Using a survey research design, this study adopts a quantitative research approach to get a complete understanding of the research problems. Research using this approach can provide reliability, causality and ability to generalize (Bryman, 2001). Since, this study is on board structure of pharmaceutical industry of 
Bangladesh, population is made up of pharmaceutical companies listed in Dhaka Stock Exchange (DSE). However, pharmaceutical companies are listed here under the category of "Pharmaceutical and Chemical Company" (Table 1), thus only listed pharmaceutical companies are considered instead of all for sample selection.

Table 1. Pharmaceuticals and chemicals companies listed in dhaka stock exchange

\begin{tabular}{cllc}
\hline Categories & & Quantity \\
\hline Total Companies & Medical Support & 4 & 25 \\
Pharmaceuticals & Chemicals & 4 & 12 \\
Others & Others & 5 & 13 \\
\hline
\end{tabular}

Source: Dhaka Stock Exchange.

Among these 12 pharmaceutical companies in DSE (Saha \& Bhuiyan, 2014), two firms have been listed recently in and after 2013 and hence. Besides, another leading pharmaceutical company prepares its annual report based on its all three main operational business units, where pharmaceutical is only one unit. So the annual report of this company does not reflect the sole effect of operational performance of pharmaceutical unit of the company. Therefore, only nine out of eleven companies are actually eligible for selecting samples. Name of the pharmaceutical companies listed in DSE are presented in Table 2.

Table 2. Listed pharmaceutical companies in DSE

\begin{tabular}{l}
\hline ACI Limited \\
Ambee Pharma \\
Beacon Pharmaceuticals Limited \\
Beximco Pharma \\
Central Pharmaceuticals Limited \\
Glaxo SmithKline \\
The Ibn Sina \\
Orion Pharma Ltd. \\
Reckitt Benckiser (BD) Ltd. \\
Renata Ltd. \\
Square Pharmaceuticals Ltd \\
\hline
\end{tabular}

Source: Dhaka Stock Exchange.

Eligible 9 firms have been selected for a period of 10 years (2005-2014), generating a total observations of 90 . Thus, this study considers 9 pharmaceutical companies listed on the Dhaka Stock Exchange (DSE) which represents $75 \%$ of the total listed pharmaceutical companies December, 2014.

\subsection{Data Collection}

Company's accounting information, such as, total assets, total liabilities and equities, net sales, net income, operating income, operating expenses, executive's pay, has been collected from these annual reports. Other issues like, total number of directors, number of outside independent directors and CEO duality are also collected from the same sources. Some market value of the closing share price was collected from Dhaka Stock Exchange web page (at www.dsebd.org) and from the DSE library resources.

\subsection{Dependent and Independent Variable}

In the study, two different dependent variables have been adopted to measure firm's financial performance. One is Return on Assets (ROA) (an accounting based performance measure)-calculated as "Earnings before Interest and Taxes" (EBIT) scaled by the book value of total assets and another one is Tobin's Q-the ratio of the market value of the firm to the replacement cost of their assets (a market based performance measure). Based on the existing relevant empirical studies, the independent variables for this study are-board composition, board size, board ownership and CEO duality. Board composition refers to the percentage of membership held by the outside independent directors. Board size represents the total number of directors on the board. Moreover, board ownership refers to the proportion of the total equity owned by executive and non-executive directors 
respectively. CEO-duality is considered as a binary, which is equal to be one (1) if the CEO and chairperson positions are held by the same individual, otherwise zero (0), all of which has also been considered in prior studies (Rashid, 2009; Rashid et al., 2010a; Uadiale, 2010).

\subsection{Statistical Analysis}

In order to examine the relationship between board structure and firm performance, the following model is developed:

$$
Y_{i, t}=\alpha+\beta_{1} \text { BDCOMP }_{i, t}+\beta_{2} \text { BDSIZE }_{i, t}+\beta_{3} \text { BDOSHIP }_{i, t}+\beta_{4} C E O D_{i, t}+\varepsilon
$$

Where,

$\mathrm{Y}_{i}$, is alternatively $\mathrm{ROA}_{i}$, and Tobin's $\mathrm{Q}_{i}$,

$\mathrm{BDCOMP}_{i}$, is the board composition for $i$ th firm at time $t$,

BDSIZE $_{i}$, is the board size for $i$ th firm at time $t$,

$\mathrm{BDOSHIP}_{i}$, is the board ownership for $i$ th firm at time $t$,

$\mathrm{CEOD}_{i}$, is the CEO duality for $i$ th firm at time $t$,

$\alpha$ is the intercept, $\beta_{i}$ is the regression coefficient and $\varepsilon$ is the error term,

The subscript $i$ represents the different firms and $t$ represents the different years.

\section{Empirical Result Analysis}

Table 3. Descriptive statistics

\begin{tabular}{lcccccc}
\hline Variables & Minimum & Maximum & Mean & Standard Deviation & Skewness & Kurtosis \\
\hline Tobin's Q Ratio & 0.693 & 6.145 & 2.870 & 1.456 & 0.670 & -0.031 \\
Return on Asset & 0.044 & 0.285 & 0.150 & 0.067 & -0.263 & -0.851 \\
Board Composition & 0.091 & 0.250 & 0.151 & 0.054 & 0.993 & -0.433 \\
Board Size & 7.000 & 11.000 & 8.300 & 1.264 & 0.705 & -0.117 \\
Board Ownership & 0.000 & 0.345 & 0.137 & 0.142 & 0.433 & -1.471 \\
CEO Duality & 0.000 & 1.000 & 0.200 & 0.407 & 1.580 & 0.527 \\
\hline
\end{tabular}

To test the propositions made on this study, this section is devoted to present the result of the analysis conducted on collected data. Data has been analyzed using the Statistical Package for Social Sciences, (SPSS Version 16.0). The descriptive statistics of all the variables used in the study are shown in table 3 . As shown in the table, average firm performance is $287 \%$ ranging from $69.30 \%$ to $614.50 \%$ under Tobin's Q performance measure and $15 \%$ ranging from $4.40 \%$ to $28.5 \%$ under the ROA performance measure. It indicates that for every BDT 100 invested as asset there is a return of BDT 15 . The average board composition is found to be $15.10 \%$ ranging from $9.10 \%$ to $25 \%$. The result indicates that, there is $15.10 \%$ outside directors sitting on the board for selected firms of the study. On the other hand, the average board size is 8.30 directors, ranging from a minimum of 7 directors to a maximum of 11 directors. The result also indicates that the proportion of total equity owned by executive and non-executive directors is $13.70 \%$ ranging from $0 \%$ to $34.50 \%$. The categorization of the sample revealed that approximately $20 \%$ of the sample firms have the CEO duality. It indicates that $80 \%$ of the sampled firms have separate persons occupying the positions of the chief executive and the board chair and $20 \%$ of those have the same person occupying the both positions. The skewness and Kurtosis of the variables show that the data are linear and normally distributed.

Table 4. Correlation coefficient among variables

\begin{tabular}{ccccccc}
\hline & TOBQ & ROA & BDCOMP & BDSIZE & BDOSHIP & CEODUAL \\
\hline TOBQ & 1 & & & & & \\
ROA & $0.777^{* *}$ & 1 & & & & \\
BDCOMP & 0.200 & 0.208 & 1 & & & \\
BDSIZE & $-0.628^{* *}$ & $-0.749^{* *}$ & -0.338 & 1 & & \\
BDOSHIP & -0.279 & -0.197 & $-0.511^{* *}$ & $0.394 *$ & 1 & \\
CEODUAL & 0.149 & $0.363^{*}$ & 0.256 & -0.389 & $-0.487^{* *}$ & 1 \\
\hline
\end{tabular}

Note. $*$ Correlation is significant at the 0.05 level (2-tailed). $* *$ Correlation is significant at the 0.01 level (2-tailed). 
To measure the degree of multicollinearity among the variables, Pearson correlation analysis is conducted on the variables. The results are shown in Table 4. Tobin's Q is positively related with ROA and is significant at the level of 0.01. Moreover, similar result is also come out for board composition and CEO duality though not significant. However, Tobin's Q is negatively related with board size (significant at the level of 0.01) and board ownership (not significant). On the other hand, beside a positive association with Tobin's Q, ROA is positively related with board composition and CEO duality though not significant. However, it is negatively associated with both board ownership (insignificant) and board size (significant at the level of 0.01). Moreover, a negative relation is observed between board size and board ownership and is significant at the level of 0.05 . On the other hand, there is a negative association between board ownership and CEO duality (significant at the level of 0.01). A negative association is found between board ownership and board composition (significant at the level of 0.01). Thus, multicollinearity is not a problem in the distribution as the highest correlation amongst the explanatory variables found is -0.511 , which is acceptable (Haniffa \& Hudaib, 2006). VIF test confirms that there is no presence of unacceptable multicollinearity issue.

Table 5. Board structure and firm performance under different performance measures

\begin{tabular}{ccc}
\hline & \multicolumn{2}{c}{ Dependent Variable } \\
\cline { 2 - 3 } Intercept & Tobin's Q & ROA \\
\cline { 2 - 3 } BDCOMP & 9.584 & 0.464 \\
& $(4.4743)^{*}$ & $(6.011)^{*}$ \\
BDSIZE & -1.141 & 0.004 \\
& $(-0.234)$ & $(0.002)$ \\
BDOSHIP & -0.755 & -0.040 \\
& $(-3.750)^{*}$ & $(-5.187)^{*}$ \\
CEODUAL & -1.205 & 0.084 \\
& $(-0.586)$ & $(1.066)$ \\
Adjusted R Square & -0.546 & 0.025 \\
F Statistics & $(-0.842)$ & $(1.013)$ \\
& $0.319^{*}$ & $0.523^{*}$ \\
\hline
\end{tabular}

Note. $*$ Correlation is significant at the 0.01 level (2-tailed).

Table 5 shows the results of the coefficient estimates with both Tobin's Q and ROA as dependent variable. Besides, the table also shows the model summary of regression analysis with adjusted $\mathrm{R}$ square measure and $\mathrm{F}$ statistics value. The adjusted $\mathrm{R}$ square value, indicating the explanatory power of the independent variables, is 0.319 and 0.523 respectively for Tobin's Q and ROA. It indicates that $31.90 \%$ of the variation in Tobin's Q and $52.30 \%$ of the variation in ROA is explained by the variation in the independent variables. From the result of the analysis, the analysis of variance (ANOVA) generates a significant p-value of 0.008 and 0.000 for Tobin's Q and ROA respectively, indicating model is significant at level of 0.01 . This shows that the explanatory variables are linearly related to both measures of firm's performance and the model seems to have some validity.

Table 5 also shows that only board size is significantly associated with both dependent variables and in both cases it is significant at the level of 0.01 . It also indicates that, board size is negatively related with Tobin's Q. Moreover, a similar negative association is expressed between board size and ROA. Tobin's Q is negatively associated with others independent variables (e.g. board composition, board ownership and CEO duality) but it is not significant. On the other hand, ROA is positively associated with other independent variables (e.g. board composition, board ownership and CEO duality) but it is also not significant.

\section{Conclusion}

The aim of this study is to empirically examine the impact of board structure on financial performance in listed pharmaceuticals companies of Bangladesh. Based on previous empirical studies of this nature, a number of variables have been identified that to explain the financial performance of companies. Collected data on these variables including Tobin's Q, ROA, Board Composition, Board Size, Board Ownership, and CEO duality are thus analyzed to test the hypothesis proposed in the study. 
Results generated from the data analysis show that there is a strong negative association between board size and firm's financial performance. The result is significantly consistent for both market based performance measure (Tobin's Q ratio) and accounting based performance measure (ROA). Though average board size of 8 members is consistent with the suggestion of Jensen (1993) and Lipton and Lorsch (1992), such a board is only responsible for a negative financial performance for listed pharmaceutical companies of Bangladesh.

Other than the board size, there is no significant relationship between selected independent variables and firm's financial performances. This finding indicates some similarity with Rashid (2009) and Rashid et al. (2010a). Besides, the proportion of outside independent directors in board is only $14.60 \%$ on average; indicating that they certainly have little influence in firm's performance. A board consist of majority inside directors have no significant relationship with firm's financial performance. Lack of monitoring, transparency and too concentrated of family ownership might be the reason. Moreover, confirming the situation, descriptive statistics also shows that for the sampled firm, financial performance is very poor under accounting performance measures, whereas it is surprisingly outstanding under the market based performance measures. This finding is similar with Rashid (2009) and Rashid et al. (2010a).

Therefore, this study recommends that a small but representative board size for pharmaceutical companies of Bangladesh. As board of directors are supposed to ensure monitoring the activities to increase firm performance, the composition of outside directors as members of the board should be increased so that it could be representative. Furthermore, this study may be improved by including more firms and some other variables that may affect corporate financial performance. This study could be further extended to other industry and a comparative analysis could be performed between Bangladesh and other developing countries.

\section{References}

Adams, R., \& Mehran, H. (2003). Is Corporate Governance Different for Bank Holding Companies? Economic Policy Review, 9, 123-142. http://dx.doi.org/10.2139/ssrn.387561

Adams, R., \& Mehran, H. (2005). Corporate performance, board structure and its determinants in the banking industry. Working paper, Federal Reserve Bank of New York.

Adams, R., Almeida, H., \& Ferreira, D. (2005). Powerful CEOs and their Impact on Corporate Performance. Review of Financial Studies, 18(4), 1403-1432. http://dx.doi.org/10.1093/rfs/hhi030

Awan, S. H. (2012). Effect of board composition on firm's performance: A case of Pakistani listed companies. Interdisciplinary Journal of Contemporary Research in Business, 3(10).

Beiner, S., Drobetz, W., Schmid, F., \& Zimmermann, H. (2004). Is board size an independent corporate governance mechanism? Kyklos, 57, 327-356. http://dx.doi.org/10.1111/j.0023-5962.2004.00257.x

Beiner, S., Drobetz, W., Schmid, M. M., \& Zimmermann, H. (2006). An integrated framework of corporate governance and firm valuation. European Financial Management, 12, 249-283. http://dx.doi.org/10.1111/j.1354-7798.2006.00318.x

Berkman, H., Cole, R. A., Lee, A., \& Veeraraghavan, M. (2005). The Effect of Board Composition and Ownership Structure on Firm Performance: Evidence from India. The 2005 China International Conference in Finance held July 5-7, 2005 in Kunming, PRC.

Bermig, A., \& Frick, B. (2010). Board Size, Board Composition and Firm Performance: Empirical Evidence from Germany. Resulted from a research project financed by the Hans Boeckler Foundation, Duessel-dorf. http://dx.doi.org/10.2139/ssrn.1623103

Boone, A. L., Field, L. C., Karpoff, J. M., \& Raheja, C. G. (2007). The determinants of corporate board size and composition: An empirical analysis. Journal of Financial Economics, 85, 65-101. http://dx.doi.org/10.1016/j.jfineco.2006.05.004

Brennan, N. (2006). Boards of Directors and Firm Performance: Is There an Expectations Gap? Corporate Governance: An International Review, 14(6), 577-593. http://dx.doi.org/10.1111/j.1467-8683.2006.00534.x

Brickley, J., Coles, J., \& Linck, J. (1999). What happens to CEOs after they retire? New evidence on career concerns, horizon problems, and CEO Incentives. Journal of Financial Economics, 52, 341-377. http://dx.doi.org/10.1016/S0304-405X(99)00012-4

Bryman, A. (2001). Social Research Method. Oxford University Press.

Cadbury, S. A. (1992). Committee on the Financial Aspects of Corporate Governance. United Kingdom, London Stock Exchange. 
Callen, J. L., Klein, A., \& Tinkelman, D. (2003). Board Composition, Committees, and Organizational Efficiency: The Case of Nonprofits. Nonprofit and Voluntary Sector Quarterly, 32(4), 493-520. http://dx.doi.org/10.1177/0899764003257462

Cannella, A. A., \& Lubatkin, M. (1993). Succession as a socio-political process: Internal impediments to outsider selection. Academy of Management Journal, 36(4), 763-793. http://dx.doi.org/10.2307/256758

Chatterjee, S. H. D. (2011). Board Composition and Performance in Indian Firms: A Comparative Analysis Empirical. The International Journal of Management Science and Information Technology (IJMSIT), 1(2), $1-15$.

Cheng, S., Evans III, J. H., \& Nagarajan, N. (2008). Board size and firm performance: the moderating effects of the market for corporate control. Review of Quantitative Finance and Accounting. http://dx.doi.org/10.1007/s11156-007-0074-3

Coles, J. L., Daniel, N. D., \& Naveen, L. (2008). Boards: Does one size fit all? Journal of Financial Economics, 87, 329-356. http://dx.doi.org/10.1016/j.jfineco.2006.08.008

Connelly, J. T., \& Limpaphayom, P. (2004). Environmental reporting and firm performance: Evidence from Thailand. The Journal of Corporate Citizenship, 13(1), 37-149.

Daily, C., \& Dalton, D. (1997). CEO and board chair roles held jointly or separately: Much ado about nothing? The Academy of Management. http://dx.doi.org/10.5465/AME.1997.9709231660

Dalton, D., Daily, C., Johnson, J., \& Ellstrand, A. (1999). Number of directors and financial performance: A meta-analysis. Academy of Management Journal, 42, 674-686. http://dx.doi.org/10.2307/256988

Darmadi, S. (2010). Board diversity and firm performance: The Indonesian evidence. MPRA Paper No. 38721 , posted 10. May 2012.

Davis, J. H., Schoorman, D., \& Donaldson, L. (1997). Toward a Stewardship Theory of Management. Acad Manage Review, 22(1), 20-47. http://dx.doi.org/10.2307/259223

Dehaene, A., De Vuyst, V., \& Ooghe, H. (2001). Corporate Performance and Board Structure in Belgian Companies. Long Range Planning, 34(3), 383-398. http://dx.doi.org/10.1016/S0024-6301(01)00045-0

Demsetz, H. (1983). The structure of equity ownership and the theory of the firm. Journal of Law and Economics, 26, 375-390. http://dx.doi.org/10.1086/467041

Demsetz, H., \& Lehn, K. (1985). The structure of corporate Ownership: Causes and Consequences. Journal of Political Economy, 95(6), 1155-1175. http://dx.doi.org/10.1086/261354

Donaldson, L., \& Davis, J. (1991). Stewardship theory or Agency theory: CEO governance and shareholder returns. Australian Journal of Management, 16(1), 49-64. http://dx.doi.org/10.1177/031289629101600103

Eisenberg, T., Sundgren, S., \& Wells, M. T. (1998). Larger board size and decreasing firm value in small firms. Journal of Financial Economics, 48, 35-54. http://dx.doi.org/10.1016/S0304-405X(98)00003-8

Eisenhardt, K. M. (1989). Agency theory: An assessment and review. Academy of Management Review, 14(1), 57-74. http://dx.doi.org/10.2307/258191

Erhardt, N. L., Werbel, J. D., \& Shrader, C. B. (2003). Board of Director Diversity and Firm Financial Performance. Corporate Governance: An International Review, 11(2), 102-111. http://dx.doi.org/10.1111/1467-8683.00011

Fauzi, F., \& Locke, S. (2012). Board structure, ownership structure and Firm performance: A study of New Zealand listed-firms. Asian Academy of Management Journal of Accounting and Finance, 8(2), 43-67.

Finkelstein, S., \& D’Aveni, R. A. (1994). CEO duality as a double-edged sword: How boards of directors balance entrenchment avoidance and unity of command. Acad Manage Journal, 37(5). http://dx.doi.org/10.2307/256667

Gillan, S. L. (2006). Recent developments in corporate governance: An overview. Journal of Corporate Finance, 12(3), 381-402. http://dx.doi.org/10.1016/j.jcorpfin.2005.11.002

Goodstein, J., Gautum, K., \& Boeker, W. (1994). The effect of Board size and Diversity on Strategic Change. Strategic Management Journal, 15(3), 241-250. http://dx.doi.org/10.1002/smj.4250150305

Guest, P. M. (2008). The determinants of board size and composition: Evidence from the UK. Journal of Corporate Finance, 14, 51-72. http://dx.doi.org/10.1016/j.jcorpfin.2008.01.002 
Haniffa, R., \& Hudaib, M. (2006). Corporate governance structure and performance of Malaysian listed companies. Journal of Business Finance \& Accounting, 33, 1034-1062. http://dx.doi.org/10.1111/j.1468-5957.2006.00594.x

Harris, D., \& Helfat, C. E. (1998). CEO duality, succession, capabilities and agency theory: Commentary and research agenda. Strategy Manage Journal, 19(9), 901-904. http://dx.doi.org/10.1002/(SICI)1097-0266(199809)19:9<901::AID-SMJ2>3.0.CO;2-V

Hermalin, B. E., \& Weisbach, M. S. (2003). Boards of directors as an endogenously determined institution: A survey of the economic evidence. Economic Policy Review, 9, 7-26.

Huq, B. I. A., \& Bhuiyan, M. Z. H. (2012). Corporate Governance-It's Problems \& Prospects in Banking Industry in Bangladesh. World Review of Business Research, 2(2), 16-31.

Huther, J. (1997). An empirical test of the effect of board size on firm efficiency. Economics Letters, 54, $259-264$. http://dx.doi.org/10.1016/S0165-1765(97)00035-9

Jensen, M. C. (1993). The Modern Industrial Revolution, Exit, and the Failure of Internal Control Systems. Journal of Finance, 48(3), 831-880. http://dx.doi.org/10.1111/j.1540-6261.1993.tb04022.x

Kumar, N., \& Singh, J. P. (2012). Outside Directors, Corporate Governance and Firm Performance: Empirical Evidence from India. Asian Journal of Finance \& Accounting, 4(2). http://dx.doi.org/10.5296/ajfa.v4i2.1737

Latif, B., Shahid, M. N., Haq, M. Z. U., Waqas, H. M., \& Arshad, A. (2013). Impact of Corporate Governance on Firm Performance: Evidence from Sugar Mills of Pakistan. European Journal of Business and Management, $5(1)$.

Lehn, K., Sukesh, P., \& Zhao, M. (2004). Determinants of the size and structure of corporate boards: 1935-2000. Working Paper, Katz Graduate School of Business.

Liang, N., \& Li, J. (1999). Board Structure and Firm Performance: New Evidence from China's Private Firms. Academy of Management Annual Conference, Chicago, USA, August 7-10, 1999.

Linck, J., Netter, J., \& Yang, T. (2008). The determinants of board structure. Journal of Financial Economics, 87, 308-328. http://dx.doi.org/10.1016/j.jfineco.2007.03.004

Lipton, M., \&. Lorch, J. W. (1992). A Modest Proposal for improved Corporate Governance. The Business Lawyer, 48(1), 59-77.

Loderer, C., \& Peyer, U. (2002). Board overlap, seat accumulation and share prices. European Financial Management, 8, 165-192. http://dx.doi.org/10.1111/1468-036X.00183

Mak, Y. T., \& Kusnadi, Y. (2005). Size really matters: Further evidence on the negative relationship between board size and firm value. Pacific-Basin Finance Journal, 13, 301-318. http://dx.doi.org/10.1016/j.pacfin.2004.09.002

McConnell, J. J., \& Servaes, H. (1990). Additional evidence on equity ownership and corporate value. Journal of Financial Economics, 27, 595-612. http://dx.doi.org/10.1016/0304-405X(90)90069-C

Morck, R., Schleifer, A., \& Vishny, R. W. (1988). Management ownership and market valuation: An empirical analysis. Journal of Financial Economics, 20, 293-315. http://dx.doi.org/10.1016/0304-405X(88)90048-7

Moscu, R. G. (2013). The Relationship between Firm Performance and Board Characteristics in Romania. International Journal of Academic Research in Economics and Management Sciences, 2(1).

Ness, R. K. V., Miesing, P., \& Kang, J. (2010). Board of Director Composition and Financial Performance in a Sarbanes-Oxley World. Academy of Business and Economics Journal, 10(5), 56-74.

Pearce, H., \& Zahra, S. A. (1992). Board Composition from a Strategic Contingency Perspective. Journal of Management Studies, 29, 411-438. http://dx.doi.org/10.1111/j.1467-6486.1992.tb00672.x

Pfeffer, J. (1983). Organizational demography. In L. L. Cummings \& B. M. Staw (Eds.), Research in organizational behaviour (Vol. 5, pp. 299-357). Greenwich, CT: JAI Press.

Postma, T. J. B. M., Ees, H. V., \& Sterken, E. (1996). Board Composition and Firm Performance in the Netherlands. University of Groningen, Faculty of Management and Organization and Faculty of Economics.

Ranasinghe, D. N. (2010). Composition and Configuration of the Board and Firm Performance. ICBI 
2010-University of Kelaniya, Sri Lanka.

Rashid, A., Fairuz, R., \& Husein, Z. (2010). A new perspective on board composition and firm performance in an emerging market. Corporate Governance: The International Journal of Business in Society, 10(5), 647-661. http://dx.doi.org/10.1108/14720701011085607

Rashid, A. (2009). Board Composition, Board Leadership Structure and Firm Performance: Evidence from Bangladesh. The Accounting and Finance Association of Australia and New Zealand (AFAANZ) Annual Conference, 5-7th July, Adelaide, South Australia.

Rashid, A., \& Lodh, S. C. (2008). The Influence of Ownership Structures and Board Practices on Corporate Social Disclosures in Bangladesh. Research in Accounting in Emerging Economies, 8, 211-237. http://dx.doi.org/10.1016/S1479-3563(08)08008-0

Rashid, A., Zoysa, A. D., Lodh, S., \& Rudkin, K. (2010). Board Composition and Firm Performance: Evidence from Bangladesh. Australasian Accounting Business and Finance Journal, 4(1), 76-95.

Roberts, J., McNulty, T., \& Stiles, P. (2005). Beyond agency conceptions of the work of non-executive director: Creating accountability in the boardroom. British Journal of Management, 16(1), 5-26. http://dx.doi.org/10.1111/j.1467-8551.2005.00444.x

Saad, K. S. (2012). An Overview of the Pharmaceutical Sector in Bangladesh. BRAC EPL Research.

Saha, A. K., \& Arifuzzaman. (2011). Management Disclosures on Internal Control in Annual Reports-A Study on Banking Sector: Bangladesh Perspective. International Journal of Economics and Finance, 3(5), $216-222$. http://dx.doi.org/10.5539/ijef.v3n5p216

Saha, A. K., \& Bhuiyan, A. R. (2014). Predictability of Share Prices through Corporate Annual Reporting: A Focus on the Dhaka Stock Exhange. Journal of Applied Management Accounting Research, 12(2), 75-86.

Saha, A. K., \& Akter, S. (2013). Corporate governance and voluntary disclosure practices of financial and non-financial sector companies in Bangladesh. Journal of Applied Management Accounting Research, 11(2), $45-62$

Sami, H., Wang, J. T., \& Zhou, H. (2008). Corporate Governance and Operating Performance of Chinese Listed Firms. The 2008 Annual Congress of the European Accounting Association and the 2008 Annual Meeting of the American Accounting Association.

Shakir, R. (2008). Board Size, Board Composition and Property Firm Performance. Economy, 53(2), $123-138$.

Shleifer, A., \& Vishny, R. W. (1997). A survey of corporate governance. Journal of Finance, 52(2), 737-783. http://dx.doi.org/10.1111/j.1540-6261.1997.tb04820.x

Uadiale, O. M. (2010). The Impact of Board Structure on Corporate Financial Performance in Nigeria. International Journal of Business and Management, 5(10), 155-166.

Yermack, D. (1996). Higher market valuation of companies with a small board of directors. Journal of Financial Economics, 40(2), 185-211. http://dx.doi.org/10.1016/0304-405X(95)00844-5

\section{Copyrights}

Copyright for this article is retained by the author(s), with first publication rights granted to the journal.

This is an open-access article distributed under the terms and conditions of the Creative Commons Attribution license (http://creativecommons.org/licenses/by/3.0/). 